\title{
EFFECT OF STUDENT LEARNING MODEL ON EMOTIONAL INTELLIGENCE
}

\author{
Pulung Riyanto \\ Department of Physical Education Health and Recreation, \\ Faculty of Teacher Training and Education, Universitas Musamus, Merauke, Indonesia \\ Philipus Betaubun \\ Civil Engineering Department, Faculty of Engineering, \\ Universitas Musamus, Mrauke, Indonesia
}

\begin{abstract}
The era of globalization requires someone to have intelligence in facing all difficulties and challenges, not closing the possibility of physical education learning. In this study, an increase in emotional intelligence was developed using learning models. The research model used was quasi-experiment with the design of the pretest post-test two treatment design. Emotional intelligence plays a role in realizing educational goals, this is expected to increase conducive learning. In learning emotional intelligence is not very popular but is a basis for assessing students 'abilities and for understanding students' feelings. Emotional intelligence is expected to be a determining factor in the bridge to achieve learning outcomes. It is expected that teachers of Physical Education in using Emotional intelligence can use Inquiry learning models.
\end{abstract}

Keywords: Emotional Intelligence, Problem Based Learning, Inquiry Learning

Cite this Article: Pulung Riyanto, Philipus Betaubun, Effect of Student Learning Model on Emotional Intelligence, International Journal of Management (IJM), 10 (6), 2019, pp. 54-60.

http://iaeme.com/Home/issue/IJM?Volume $=10 \&$ Issue $=6$

\section{INTRODUCTION}

Emotional intelligence is obtained because of the awareness of an object that begins with the knowledge of the object and how it interacts with the object. For example, athletes who want to achieve and realize that the importance of maintaining emotions so that they can still think has a greater chance of success compared to athletes who do not have emotional intelligence. Emotional intelligence plays an important role in achieving success in school and college, and also plays a role in terms of students' psychology (Baksh Baloch, Saleem, Zaman, \& Fida, 2014)

Emotions need to be trained by increasing understanding related to the effects of negative and positive emotions. This means that if managed properly then emotions are a driver to act and become a force that can determine one's success, especially in the education of physical education. Physical Education Students must learn about the assignments and roles of students. 
Teachers in learning have a role as communicators, informants, managers, mentors, role models and parents (Daneshmand, 2013).

Emotional Intelligence or Emotional Quotient (EQ) plays an important role in realizing educational goals. This is useful to foster conducive learning conditions between students and educators so that they have a common vision so that they will be able to formulate learning missions together. It takes the teacher's ability to manage student emotional intelligence, the teacher has many roles to play in carrying out the duties as a communicator, a disciplinary, a conveyor of information, a classroom manager, a counselor, a decision-maker, a role model, and a surrogate parent. Preparation programs for each preparation (Daneshmand, 2013).

Handball learning must emphasize collaboration associated with emotions possessed by students. Teachers in the learning process must monitor emotions to encourage children towards cooperation, this is in line with "It means overseeing emotions with the goals that they are communicated fitting, empowering individuals to cooperate easily towards their normal objectives (Kaur \& Singh, 2018). which is developed using the National Curriculum is expected that students will become active and cause high motivation in learning. Active activities are expected to lead to an increase in muscle strength, improve fitness and skills in handball learning. One aspect in the handball includes emotions, emotions have a role in learning in school. "Students' emotional intelligence can be defined as someone's drive to do something willing. This is a situation that can be observed from the outside(Khan, Ali, \& Ahmad, 2016).

Handball is taught in schools, where it is played by teams demanding students to establish relationships with other students. The game performed in learning is expected to require students to develop their emotional intelligence, in the hope of developing games and instructions given by the teacher. "Emotional intelligence has its roots in Gardner's interpersonal and intrapersonal intelligence" (Zamanian, Haghighi, Forouzandeh, Sedighi, \& Salehian, 2011). To get the maximum score or victory, students are expected to have the ability to place positions. The ability to place can be based on emotional intelligence. Emotional intelligence comes from someone's interpersonal and intrapersonal intelligence (Zamanian et al., 2011).

In the school environment, someone's emotional intelligence is different. Students' abilities both in psychomotor, cognitive and affective aspects can be based on the emotional intelligence of the students themselves. Improvement of learning is not only done in learning but can be done in extracurricular activities. Achievement improvements can be supported by high emotional intelligence possessed by students. Researchers in sports psychology show that athletes who have high emotional intelligence scores will become successful athletes in sports. Athletes' emotional intelligence is related to the performance of athletes in achieving success (Akelaitis \& Malinauskas, 2018).

Andi Defines emotional intelligence Intellectuality is said to be the ability to understand, manage feelings and emotions of students and others, to distinguish between students, and use this information to guide one's thoughts and actions (Andi, 2012). The purpose of the above opinion is that researchers define EQ as the ability to understand and manage the feelings and emotions of others and themselves, to distinguish between them, and to use the information to guide one's thoughts and actions. Emotional intelligence is defined as the ability to understand and recognize emotions, assimilation of emotions, understand messages and emotional meanings (Gunu \& Oladepo, 2014).

Emotional intelligence as the ability to understand and recognize emotions, to assimilate emotions, to understand messages and meanings of emotions. Mayer and Salovey in Tahir Mehmood "Emotional intelligence and other individuals, using feelings to improve execution, comprehension of feelings and enthusiastic information, and direct feelings in the self and in other individuals (Ahmed, Sabir, Rehman, Khosa, \& Khan, 2016). Emotional intelligence is a 
combination of abilities that combine the possibility to distinguish feelings in oneself and in other individuals, utilize feelings to increase execution, understand enthusiastic feelings and information, and direct feelings in self and other individuals.

Emotional intelligence as an ability and emotional awareness to handle feelings, realize the feelings of others, be able to empathize, entertain, guide, the ability to control impulses, delay satisfaction, motivate themselves, read other people's social cues and deal with the ups and downs of life. These researchers regard emotional intelligence as a series of skills that combine cognitions (thoughts) and emotions (feelings) (Ahmed et al., 2016). PBL is a learning approach where students are faced with authentic problems so that they are expected to develop their knowledge, develop high-level skills and inquiry, empower students, and increase their selfconfidence. The model of learning problem-based learning is a more active atmosphere with discussion, debate, controversy clan, greater student curiosity, PBL is a teaching method that is motivating students to achieve academic success (Rubiah, 2016).

In addition to the above definition regarding the understanding of learning model PBL is a learning method that is characterized by the real problems as a context for students to learn critical thinking and problem-solving skills, and acquire knowledge.In addition to knowing about the understanding of PBL learning models, another thing that is not less important is that the PBL learning model is one form of learning model that develops in the world of education. This model is developed in developing countries, such as the Americas and Europe. ProblemBased Learning is an advancement in vocational education that has been taken up in tertiary education at the undergraduate level in Australia, on the American continent and Europe within the last two decades (Hillman, 2003).

PBL learning model can be assumed as a learning model that can involve students directly in real life. Another thing is to be able to integrate between students' knowledge and discipline, this is similar to what was stated by: "PBL is the most useful way for engaging students in a learning process based upon real-life-like situations which knowledge from different disciplines is to be integrated (Giani \& Martone, 1998).From some of the descriptions above It can be concluded that PBL is a learning model that emphasizes students on the real problem. Problems faced by students can be applied at the beginning of learning. The PBL learning model is one of the most innovative learning models in which packaged scenarios are included which encourage students to be active in the learning process. PBL can be said as a learning model which is curriculum development and learning process.

The curriculum in the learning process is packed with various problems that encourage students to acquire important knowledge. Another thing that is developed is to encourage students to solve problems and have proficiency in learning tactics. The learning process uses a structured approach to solving problems or challenges needed by students. The main principle of PBL is based on maximizing investigative learning, explanation, starting with real and meaningful problems. Therefore, PBL is the art of problem-solving (Oğuz Ünver \& ARABACIOĞLU, 2011).

The inquiry comes from the word inquire which means observation or investigation. Regarding the inquiry learning model, it must first be understood about the definition of the model itself. Metzler explained the definition of the model, namely: The model is used to be carried out in the learning process. The models provide written plans, detailed drawings, including instructions, measurements, locations, and materials that help build students, understand the object when finished learning (Metzler, 2017).Then regarding the Three inquiry model, there is no model of inquiry that is formally designed in physical education. The model ... the problem of investigation and problem-solving is that it has been used by many different types of physical educators: indirect teaching, problem-solving, exploration teaching, guided discovery (Metzler, 2017).Then many are also known as inquiry-based learning. Discovery 
learning is a constructivist-based learning model with education in the learning process with problem-solving. In the learning process where the teacher utilizes the experience, it is associated with knowledge and facts related to the latest findings. As a result, students are likely to be more likely to remember the concepts and knowledge that they found themselves (Günay Balım, 2009).

Implementation of the inquiry learning model provides a situation of student-centered learning through an investigation of a problem. Student-centered learning and students are taught how to learn and solve problems through an investigation process. In the inquiry learning process, active learning takes place by students to be able to develop students' understanding by asking questions, investigating and observing on their own compared to just being told by the teacher, so the inquiry learning model is a science-based learning model. By frequently using inquiry learning models in schools, emotional intelligence will increase and will have an impact on understanding self-concepts. This self-concept is expected to increase the feelings of the present and the future. This is in line with the attitude of the concept that is more likely to be felt by someone about himself, attitude about his current or future condition, attitude about self-pride, pride, ashamed feeling, (Herdjiono, Puspa, Maulany, \& Aldy, 2017).

Based on several statements that have been stated, it can be concluded that the inquiry model is a student-centered learning model to be directed at active learning through the problems presented by the teacher in the form of questions. Students are guided and encouraged to be able to explore the possible answers to these questions as a solution then poured into motion activities. That is, researchers assume that the inquiry method can be used to develop problemsolving skills as well as developing students' basic technical skills. The inquiry model can be used to develop students' intellectuals, help students become expressive, creative and have skills in the psychomotor field.

\section{METHODOLOGY}

The research model used was a quasi-experiment with the design of the pretest post-test two treatment design. The population of class VII students. Samples were chosen randomly using Cluster Random Sampling techniques. Methods used were Razif et al. (2006), Mangkoedihardjo (2007), Waremra and Betaubun (2018), Pratama et al. (2019). The instrument used is the Emotional Intelligence Scale developed by Schutte at all. For this study, the measurement scale uses a Likert scale which only has five choices so that it will make it easier for students to choose answers according to their circumstances.

\section{RESULTS AND DISCUSSION}

Source from the results of data analysis the author did, the author suggested the results of calculations and conclusions as follows.

Table 1. Improvement of Emotional Intelligence

\begin{tabular}{|l|l|c|c|c|c|c|}
\hline & & \multicolumn{1}{|c|}{ Mean } & $\begin{array}{c}\text { Std. } \\
\text { Deviation }\end{array}$ & $\mathbf{t}$ & df & Sig. (2-tailed) \\
\hline Pair & $\begin{array}{l}\text { PostInquiry - } \\
\text { Preinquiry }\end{array}$ & 29.47222 & 7.23281 & 24,449 & 35 & .000 \\
\hline & $\begin{array}{l}\text { postPBL - } \\
\text { prePBL }\end{array}$ & 21.27778 & 5.94552 & 21,473 & 35 & .000 \\
\hline
\end{tabular}

Based on the results of calculations in the table, it is known that the significance value for the inquiry learning model shows the number $0,000<0.05$. Ho is rejected and Ha is accepted. This suggests that there is a significant increase in emotional intelligence in the group treated 
with Inquiry learning models. In the following section, in the PBL learning model column, it is known that the significance value indicates the number $0,000<0,05$. thus, Ho is rejected and $\mathrm{Ha}$ is accepted. This indicates that there is a significant increase in emotional intelligence in the group treated by the PBL learning model.

Table 2. Differences in Emotional Intelligence

\begin{tabular}{|l|c|c|c|c|}
\hline \multicolumn{5}{|c|}{ Levene'sTest for Equality of Variances } \\
\hline \multirow{2}{*}{$\begin{array}{l}\text { Intelligence } \\
\text { Emotional }\end{array}$} & $\mathbf{F}$ & Sig. & df & Sig. (2-tailed) \\
\cline { 2 - 5 } & 2,709 & .104 & 70 & .000 \\
\cline { 2 - 5 } & & & 67,473 & .000 \\
\hline
\end{tabular}

Based on the above output, the sig value is known. Levene's Test for Equality of Variances is o. 104, it can be interpreted that the data variance between the Inquiry learning model and the PBL learning model is homogeneous. Based on the table output, the independent samples test on the Equal variances assumed section is known as sig. (2 tailed) equal to $0,000<0,05$, so as the basis of decision making in the test of the independent samples test can be concluded that $\mathrm{H}_{0}$ is rejected and $\mathrm{H}_{\mathrm{a}}$ is accepted. The assumption concludes that there is a significant difference between the average emotional intelligence of students in the group using the inquiry learning model and the PBL learning model.

$\mathrm{T}$ value in the can is 5.251> 1.99547 thus, $\mathrm{H}_{0}$ is rejected and $\mathrm{H}_{\mathrm{a}}$ accepted, means that there is a difference yan average emotional intelligence of students between the groups using the inquiry learning model and learning model PBL. In other words, the application of the inquiry learning model and the PBL learning model by the teacher will result in different emotional intelligence.

We can see an increase in emotional intelligence in the inquiry learning model and the PBL learning model in learning in the field. The inquiry model is a learning model that can create intelligent and insightful learners. With this model, students are trained to always think critically because getting students to solve a problem themselves. This model aims to train students' ability to research, explain phenomena, and solve problems scientifically. In the process of teacher inquiry in this matter only act as facilitators, resource persons, and group counselors. The students are encouraged to seek their knowledge, not filled with knowledge.

The low level of physical education learning outcomes depends on the learning process faced by students. In learning physical education, the teacher must master the material taught and how to convey it. How to deliver lessons is often also called a model or teaching style is an important factor to be considered by a teacher. But from the fact above there are still a lot of physical education teachers who are still limited in teaching physical education practical learning because various limitations provide facilities that support in physical education subjects and the use of learning models in the activities of the teaching and learning process is one approach that can be expected to improve participant learning students, who sometimes learning physical education are more theoretical than practice. Inquiry learning is one learning model that uses problem-solving teaching strategies.

PBL is learning that requires students to learn to solve problems and find solutions to these problems. PBL problem-based learning can make students learn through efforts to solve realworld problems structurally to construct student knowledge. This learning requires students to actively conduct investigations in solving problems and the teacher acts as a facilitator or mentor. PBL is learning that is conveyed by presenting a problem, asking questions, facilitating an investigation and opening the dialogue being studied should be a contextual problem found by students in daily life. Learning developed can be applied in daily life by developing the spirit of leadership both in school and in the family environment. Improvement in daily life is 
expected to improve service performance in terms of life. the style of an appropriate trainer will have an impact on strengthening service performance for students (Fitriani et al., 2018).

Problems must be solved by applying several concepts and principles that are simultaneously studied and included in the subject curriculum. In problem-based learning, attention to learning is not only about acquiring declarative knowledge, but also acquiring procedural knowledge. With the above assumptions, in the field, the researchers found the ability of students to control emotional intelligence in handball learning in junior high schools.

\section{CONCLUSION}

Learning that presents and uses many variations will increase the students' knowledge in learning. Inkuairi that is well packaged by a teacher will foster a sense of pleasure in students. The cooginitive aspect of learning becomes an important fact in achieving maximum learning outcomes. Emotional intelligence possessed by students will affect life in the present and in the future. This emotional intelligence will also have an impact on sports performance. One way to improve student emotional intelligence is to use inquiry learning models. It is suggested to physical education teachers to use inquiry learning models to improve students' emotional intelligence.

\section{REFERENCES}

[1] Baksh Baloch Q, Saleem M, Zaman G and Fida A, The Impact of Emotional Intelligence on Employees' Performance. J. Manag. Sci. 2014, 8, pp 1-7

[2] Daneshmand B 2013 Emotional Intelligence and its necessity in teaching training Int. J. Econ. Manag. Soc. Sci.2013, 2, pp 899-904

[3] Kaur R and Singh B, Comprehensive investigation of emotional intelligence between open and closed skill athletes, 2018

[4] Khan Z, Ali A and Ahmad N, The study of emotional maturity among district authority and handball players of sports authority sementhicscholar , 2016, 3, pp 454-458

[5] Zamanian F, Haghighi M, Forouzandeh E, Sedighi Z and Salehian M H 2011 A comparison of emotional intelligence in elite student athletes and non-athletes Ann. Biol. Res, 2011, 2, pp $179-83$

[6] Akelaitis A V and Malinauskas R K, The expression of emotional skills among individual and team sports male athletes Pedagog. Psychol. medical-biological Probl. Phys. Train. Sport, 2018, 22 , pp 62-67

[7] Andi H K, Emotional intelligence and personality traits: a correlational study of MYEIT and BFI Int. J. Acad. Res. Bus. Soc. Sci, 2012, 2, 285.

[8] Gunu U and Oladepo R O, Impact of Emotional Intelligence on Employees' Performance and Organizational Commitment: A Case Study of Dangote Flour Mills Workers Univ. Mauritius Res. J., 2014, 20, pp 1-32.

[9] Ahmed Z, Sabir S, Rehman U, Khosa M and Khan A, The impact of emotional intelligence on employee performance in public and private higher educational institutions of Pakistan IOSR J. Humanisties Soc. Sci. Bus. Manag, 2016, 18, pp 63-71.

[10] Rubiah M, Implementation of Problem Based Learning Model in Concept Learning Mushroom as a Result of Student Learning Improvement Efforts Guidelines for Teachers. J. Educ. Pract, 2016, 7, pp 26-30 
[11] Hillman W, Learning How to Learn: Problem Based Learning Aust. J. Teach. Educ, 2003, 8, $0-1$

[12] Mr. Kunj Karia, Study of Emotional Intelligence and its Influence in Organizational Behaviour, International Journal of Advanced Research in Management (IJARM), Volume 5, Issue 4, July- August (2014), pp. 60-65

[13] Giani U and Martone P, Distance learning, problem based learning and dynamic knowledge networks Int. J. Med. Inform, 1998,50, pp 273-8

[14] Oğuz Ü A and Arabacioğlu S, Overviews on inquiry based and problem based learning methods, 2011, 3, pp 303-309

[15] A. Sathya and Dr. V. P. Velmurugan, Role of Emotional Intelligence In Leadership Behaviour- A Review. Journal of Management, 5(3), 2018, pp. 187-191.

[16] Mangkoedihardjo, S, Physiochemical Performance of Leachate Treatment, a Case Study for Separation Technique. Journal of Applied Sciences, 2007, 7(23), pp 3827-3830.

[17] Razif, M., Budiarti, V.E., Mangkoedihardjo, S, Appropriate fermentation process for tapioca's wastewater in Indonesia. Journal of Applied Sciences, 2006, 6(13), 2846-2848.

[18] Abhishek Venkteshwar and Dr Uma Warrier, The Effect of Birth order in the Emotional Intelligence of Net Generation Students. International Journal of Management, 8 (6), 2017, pp. 69-75.

[19] Nasra Pratama, Fransiskus Xaverius Manggau, Philipus Betaubun, Attitude Quadrotor Control System with Optimization of PID Parameters Based On Fast Genetic Algorithm. International Journal of Mechanical Engineering and Technology, 2019, 10(1): 335-343.

[20] Saket Jeswani and Dr. Sumita Dave, Emotional Intelligence as an Antecedent of Turnover Intention: An Empirical Analysis on Faculty Members, International Journal of Management (IJM), Volume 3, Issue 2, May-August (2012)

[21] Richard S. Waremra and Philipus Betaubun, Analysis of Electrical Properties Using the four point Probe Method. E3S Web of Conferences, 2018, 73, 13019.

[22] Metzler M, Instructional models in physical education (Routledge), 2017

[23] Balım A G, The Effects of Discovery Learning on Students' Success and Inquiry Learning Skills. Eurasian J. Educ. Res, 2009,35, pp 1-20

[24] Dr. R. Ramachandran, Employees Emotional Intelligence Impact with Demographic Issues: A Study on Bharath Heavy Electrical Limited, Trichirapalli. Journal of Management, 5(4), 2018, pp. 62-73.

[25] Herdjiono I, Puspa Y H, Maulany G and Aldy B E, The factors affecting entrepreneurship intention Int. J. Entrep. Knowl.2017, 5, pp 5-15

[26] Fitriani F, Betaubun P, Pure E A G, Tikon D, Maturbongs E E, Cahyanti T W A and Waas R F, Relationship of employee ethnic background in Validation of Situational leadership Theory Indian J. Public Heal. Res. Dev, 2018, 9, pp 200-15 